\begin{tabular}{l|l}
$\mathbf{m}$ & south \\
$\mathbf{m} \boldsymbol{n}$ & asia
\end{tabular}

samaj multidisciplinary

uinu academic

i'.
South Asia Multidisciplinary Academic Journal

1 | 2007

Migration and Constructions of the Other

\title{
Working for India or against Islam? Islamophobia in Indian American Lobbies
}

Ingrid Therwath

\section{OpenEdition}

\section{Journals}

\section{Electronic version}

URL: http://journals.openedition.org/samaj/262

DOI: 10.4000/samaj.262

ISSN: 1960-6060

\section{Publisher}

Association pour la recherche sur l'Asie du Sud (ARAS)

\section{Electronic reference}

Ingrid Therwath, «Working for India or against Islam? Islamophobia in Indian American Lobbies », South Asia Multidisciplinary Academic Journal [Online], 1 | 2007, Online since 14 October 2007, connection on 30 April 2019. URL : http://journals.openedition.org/samaj/262 ; DOI : 10.4000/ samaj.262

This text was automatically generated on 30 April 2019.

\section{$(1) \Theta \Theta$}

This work is licensed under a Creative Commons Attribution-NonCommercial-NoDerivatives 4.0 International License. 


\title{
Working for India or against Islam? Islamophobia in Indian American Lobbies
}

\author{
Ingrid Therwath
}

1 An increasing number of articles on the Indian lobby in Washington have been published in the past 15 years, by the Indian, the American and the Pakistani press. This period coincides with two major events, one at the domestic level and the other at the international level. According to the 1990 US Census, 857,000 Indian Americans resided in the Unites States, more than twice the number a decade before (they were 350,000 in 1980). They were the fifth ethnic community in the US and were already established in the country. Besides, the end of the Cold War and that of a bipolar vision of international relations coincided with the rise of transnational groups and ethnic lobbies as political actors (Ambrosio 2002). ${ }^{1}$ The Indian lobby developed itself in this context, while India at the same time was witnessing the rise of Hindu nationalism. Now, with the post 9/11 American emphasis on the axis of evil and on the dangers of Islam, it seems the Indian lobby is using Islamophobia as a political strategy. Hence the question: is the Indian American lobby in Washington working for India or against Islam?

Of course, this question is deliberately provocative as it could be argued that both positions, pro-India activism and Islamophobia, can be reconciled. Further on the other end Indian American lobbyists claim to focus only on their community in the US and on domestic issues, far from any imported communal agenda. However, fieldwork conducted in New York and in Washington in July and August 2004 revealed virulent streaks of Islamophobia and hostility towards Pakistan amongst professional Indian American lobbyists. While not absolutely systematic, this anti-Muslim sentiment has been prominent in most of the interviews that I conducted. Constituting a population of slightly more than 1 million Hindus (approximately $52.6 \%$ of the total population of Indian Americans), the 2000 U.S. Census show that Hindus outnumber Muslims here, although their numerical superiority is not as overwhelming as it is in India. One would therefore expect this repartition to be mirrored in the membership of Indian American 
lobbies, but none of these pressure groups claiming to work for a multicultural homeland in a multicultural environment had Muslim representatives. The fact that South Asian Muslim minorities are said to identify more with coreligionists than with people hailing from the same region of the world further emphasizes a largely anti-Muslim trend among Indian American lobbies. The post-9/11 environment in the US also seems to encourage this antagonism, but on the contrary, the Indo-Pakistani peace process, with its Confidence-Building Measures and 'hands of friendship', goes against this rhetoric. The hostility of the Indian American lobbies towards Islam and Pakistan can actually be construed as the result of two separate but complementary processes: the space occupied by ethno-religious minorities in American politics on the one hand, and long-distance nationalism on the other hand. In short, Islamophobia in Indian American lobbies stems from a combination of both contingent and structural factors as well as external and internal causes.

\section{The American factors}

3 By no means does globalization negate the local dimension of modern life and a new word, 'glocalization', has even been coined to highlight the mingling of the global and the local (Robertson 1992: 173). The same concern over local factors should also be at the core of any reflection on transnational communities. I shall therefore try to root the Islamophobia I encountered in the Indian American lobby to the American context itself.

\section{Indian Americans: Divided we stand?}

4 Today, 1,9 million Indian Americans live in the United States. The latest Census data convey a very positive image of a prosperous, young, urban and educated community with an average income higher than that of the national average (Reeves \& Bennett 2004). ${ }^{2}$ Hence Indian Americans are often presented as a 'model minority', a conservative myth opposed by scholars like Daniel Sabbagh, or community activists like Christopher Dumm of the Indian American Center for Political Awareness (IACPA) (Sabbagh 2003, Dumm \& Jain 2004: 7). However, in spite of residual problems of poverty in the Indian American population, it had long been 'a minority in making', 'seen, rich, but unheard' and 'a silent Asian minority', to borrow titles of scholarly work written in the late 1980s and in the 1990s (Babu 1989, Khagram et al. 2001, Gosine 1990, Segal 1999). Of course, a variety of Indian American associations based on occupation, language, or religion exists. The website www.garamchai.com, designed as an Indian American portal, listed 333 of them spread throughout the American territory, but none of the associations mentioned are overtly political. ${ }^{3}$ Many explanations have been sought to account for this lack of political visibility: Indian Americans were either more concerned by the accumulation of capital or too divided along religious, caste, linguistic or regional lines. But, although particularly segmented, the Indian American community had not always stayed clear of political involvement.

5 At the beginning of the twentieth century Indians in the U.S. got organized for two causes: the independence of India and the suppression of racial discrimination in America. The pro-independence Ghadar party was formed in San Francisco in 1913, while individual Indians were taking legal action to be considered as Caucasians and claimed thus the American citizenship from 1910 onwards with the United States vs the Bulsara 
ruling in 1910 and later the Thind case in 1923. Others contested propriety laws excluding non-whites from land-ownership. The expulsion by American authorities of 375 Indians on the Japanese ship Komagatu Maru in 1914 gave an additional incentive for political mobilization to the Indian population in the U.S. Finally, India gained independence in 1947 and the McCarran-Walter Act (Immigration and Naturalization Act) put an end to institutionalized discrimination in 1952. Four years later, the India-born American citizen Dilip Singh Saund became a member of Congress as a representative for the State of California. In the subsequent years and especially after the 1965 immigration wave from India, the number of Indians residing in the US rose significantly. However, despite the growing diversity of Indian associations in the U.S., political lobbying was almost nonexistent till the 1970s-1980s, when the Indian government started to instrumentalize its U.S.-based diaspora more aggressively and to hire private lobbyists to air its views in Washington (Guthikonda et al. 1979: 198). ${ }^{4}$

There are now several Indian American organizations involved in lobbying, either at the local community level, or at the national level or to influence foreign policy like the Association of Indians in America (AIA, founded in the mid-1960s), the National Federation of Indian Associations (NFIA, founded in 1971 under a different name), the National Association of Americans of Asian Indian Descent (NAAAID), the Indian American Forum for Political Education (IAFPE, also called the Forum), and the Indian American Center for Political Awareness (IACPA, 1993). Two major professional associations, the American Association of Physicians of Indian Origins (AAPI) and the Asian American Hotel Owners Association (AAHOA), also devote considerable energy, time and financial resources to political lobbying. The latest addition in this mosaic of pressure groups is the US-India Political Action Committee (USINPAC, created in 2001). For the media as well as for lobbyists belonging to other communities, USINPAC has now become the most important organization in terms of membership size (the paid membership amounts to 13,500 persons while another 27,000 are non-paying active members) and access to power centres (with gala events at the Capitol Hill and joint conferences with other influential groups). It even heralds itself as 'the first and only Indian American political action committee registered with the Federal Election Commission' ${ }^{5}$ and wished to project itself as the legitimate representative of Indian interests in the U.S., as the uncontested voice of a unified community. This, however, could not be further away from the truth.

7 The division of the Indian American community has become almost proverbial over the years. During a visit to the U.S. as Prime minister of India in 2001, Atal Bihari Vajpayee has fustigated the lack of unity in the community and had deplored the fragmentation of associations whose primary goals seemed to have more to do with personal promotion than social work or political lobbying. Professional activists working directly with the India lobby also draw a sorry picture of the constant internal strife. For instance, a young 32-year-old Indian Jewish migrant working for the American Jewish Committee (AJC), one of the most powerful ethnic lobbies in the U.S., is very harsh toward Indian Americans. This deeply patriotic senior fellow in charge of international affairs and Indian-Jewish American relations is extremely critical and says that 'Indians suck you. You should never work for Indian Americans because they exploit you. They are very individualistic and very poor as a community. There is little close cooperation. Where there is success, there is ego and this is a problem'. ${ }^{6}$ Fieldwork conducted in New York and Washington reveals two main sources of division among Indian American lobbyists: personal conflicts and 
generational conflicts. Most of the times, the interviewees have devoted the first half an hour of our discussion to condemn other lobbyists and their organization. USINPAC in particular was heavily criticized. It is only after these introductory words of advice against colleagues and competitors that they started to describe their own work. The legislative affairs counsel of USINPAC, a professional lobbyist in her mid-fifties, illustrates the personal conflicts pervading throughout the community organizations and goes as far as evoking a conspiracy theory to explain the criticism faced by USINPAC amongst Indian Americans. According to her, a few of her fellow Indian American lobbyists condemn her work because she was given preference over them in 1993 when Congressman Brown gathered a delegation to visit India. She recalls that:

It's like the 'usual suspects'. I met all of them on this trip, all the 'suspects' and they come back years later to haunt you. I'm speaking about 20 people, who come from the business community-actually from the IT and technology business and no other business-and doctors. They were present during White House events hosted by Hilary Clinton. Now the doctors have gone Republican but not the others. All of them are now heading Indian American associations like IAFPA, NFIA, AIFIA. These organizations were created in the late 1970s-early 1980s as social clubs. Later they took on some political activity. These people have a clout among their own circle because they know some Congressmen. It is an issue of prestige. They donated money just to get pictures, to get the photo-op to increase their business and rise in the Indian American community. They don't have anything to ask from the politicians, they only claim clout for themselves. So when they look at USINPAC, there is a curiosity and jealousy factor. They can't or don't want to connect the money with the issue. It's just personal promotion ${ }^{7}$

8 The second divisive factor is age, now that two generations of Indian Americans are professionally and politically active. Significantly, virulent critics of USINPAC include the 39-year-old President of the Indian American Leadership Initiative (IALI), the 29-year-old Executive Director of the Indian American Center for Political Awareness (IACPA) and the 29-year-old founding President of the now defunct South Asians for Kerry (SAKI). They have repeatedly pointed out the generation gap between themselves, born and raised in America, and the 'uncle and aunties [who] don't believe in this South Asian thing'8 and who cannot see beyond the India-Pakistan and Hindu-Muslim communal conflicts. Although the younger generation is now entering the political arena, as Bobby Jindal's 2004 election to the Congress has revealed, the older Indian Americans are still leading forefront organizations like USINPAC and claim to represent the community as a whole. The older generation of activists seems more influenced by subcontinental conflicts while the younger ones see the advantage of pan-Asianism or at least of South Asian unity and tend to form South Asian organizations in order to address a wider audience. When asked about the founding of SAKI, its President remembered the opposition she encountered in the first generation of immigrants because of 'a generational gap'. According to her, 'the Indian community was fascinated by the Kashmir issue. The first generation still carries the memory of Partition' and 'the core of their message [talking about USINPAC in particular] is very anti-Muslim'. ${ }^{9}$ When asked about their Muslim membership, USINPAC leaders seem embarrassed as they did not know the figure. In the end, they come up with a 10-15\% estimate, a proportion that corresponds to the general proportion of Muslims in India and they think would hence enhance their representativity. They could not however mention one active Muslim member and none of them was Muslim either. Moreover, none of the 125 private donations made to USINPAC, since its creation, was registered in a Muslim name. ${ }^{10}$ The USINPAC members I met said they wish to defend India's positions, oppose Pakistan and told traumatic tales of Islamic fundamentalism. 
Although a few of them directly experienced Partition, they all seemed to carry its stigma and have an Indo-centric approach, by contrast with the younger America-bred activists who focused on South Asian cooperation and local community issues. The generation gap, aggravated by the fact that only $22.7 \%$ of Indian Americans were born in the U.S., all in the younger age group of course, provides a potent explanation about the pervading defiance against Islam encountered in USINPAC and other leading organizations. This observation suggests that the former generation of Indian American activists is more prone to long-distance nationalism, and generally to what has been termed 'Yankee hindtuva' than the younger lobbyists (Mathew \& Prashad 2000). But it can be argued that the American political system provided a safe haven for this long-distance religious nationalism

\section{Ethnicity and religion in the American context}

Since the end of the Cold War, American policy-makers have been paying unprecedented attention to ethnic minorities and diasporas in the US territory. In December 2000, a report entitled Global Trends 2015: A Dialogue About the Future With Nongovernment Experts and commissioned by the CIA emphasized this point by stating that 'increasing migration will create influential diasporas, affecting policies, politics and even national identity in many countries' and that 'US foreign priorities will be more transnational' ${ }^{11}$ It is not surprising in this context that the Non Resident Indians and People of Indian Origins in the US wished to organize themselves into a lobby and that control over identity definition became a crucial issue. Actually, the ethnic dimension of American foreign policy is not a new phenomenon and Yossi Shain dates ethnic lobbying back to the beginning of Irish immigration after the 1840 famine, while others view 1908 as the landmark for lobbying in the United States (Shain 1999: 12, Mohammad-Arif 2000). ${ }^{12}$ But, this phenomenon acquired a new momentum after the 1960s and especially after the end of the Cold War, which was regarded as a 'catalyst' (Ambrosio 2002). In 1975, more than fifteen years before the fall of the USSR, Glazer and Moynihan had already identified this growing trend in American politics when they wrote that 'the ethnic composition is the single most important determinant of American foreign history' (Glazer \& Moynihan 1975: 23-24). The abrogation of previous anti-lobbyist regulations in 1976 through the adoption of the Muskie-Conable Bill, which enabled registered charities to devote 1 million dollars every year to political lobbying activities, enabled many affluent groups, including ethnic minorities, to enter the political game (Abélès 2002: 107) and since then this phenomenon amplified. Indeed, in the past twenty years, multiculturalism has encouraged the creation of new ethnic lobbies that have contributed to the conflation of domestic and international issues in America (Ambrosio 2002: 10). ${ }^{13}$

Ethnic lobbies in the U.S. have been widely criticized for introducing external concerns in American domestic politics. Some scholars, like Tony Smith for example, are extremely critical of these groups which are regarded as a foreign hand (Smith 2000). Others, like Yossi Shain, have emphasized their positive contribution to the introduction of democracy and of American values in their countries of origin as they have to adopt the dominant American ideology. Some ethnic lobbyists, worried about accusations of dual allegiance, will even go as far as to deny any sympathies abroad. The Senior Legislative Counsel of USINPAC insists for example that 'we're American first. For us, the important issues are domestic issues that have nothing to do with India (...) we do not raise money 
from India and do not advocate for India', a statement in sharp contrast with USINPAC's professed mission of bettering the U.S.-India relationship and defending India's views in the U.S. In any case, whether ethnic lobbies are their home countries' ambassadors or only domestic actors spreading American values worldwide, both parties agree that ethnic lobbies can be of interest for their home countries as they (sometimes but not always) endorse the views of their home country governments. However much they wish to appear embedded in the American concern, they also 'often see themselves as representatives of their old country abroad'. In short, they have to accommodate both the American system in which they function and the homeland they wish to defend. After the fall of communism and especially under the Republican administration after the 9/11 attacks, Islam and the values of its most extremist representatives have been constructed as the new enemy of America (Shain 1999: 40). For the Indian American community, endorsing such a view, whether explicitly or implicitly meant acceptance in the American mainstream, while the secular and multi-confessional nature of their home-country demanded a softer approach of Islam. Indeed, the presentation of the Muslim as the absolute Other is at odds with the values of the Indian Constitution and the unease of many Indian American lobbyists about Islam can bee rooted down to this fundamental tension, inherent to the American system.

Eventually, another factor has led to an anti-Muslim sentiment amongst the Indian ethnic lobby. Indeed, the American political system favours ethno-religious definitions of identity and religious affiliation. The hostility between the South Asian Muslim and the Hindu communities in the U.S. are generally seen as the backlash of communal tension in India. Unrest in the diaspora after the demolition of Babri Masjid in Ayodhya seemed to confirm this analysis. However, work conducted in South California, where an important number of Indian Americans reside, by Prema Kurien has emphasized the local nature of this animosity. According to her, the American system implicitly favours a religious definition of identity and which in this particular case influences the construction of 'Indianness' along religious lines (Kurien 1997: 2). ${ }^{14}$ This context enabled hindutva, the extremist Hindu nationalist ideology instigated by the Rashtriya Swayamsevak Sangh (RSS) and its subsidiaries, to become the dominant ideology behind Hindu associations in the U.S, who gave voice to the idea of India as a Hindu Rashtra (a Hindu state). At the same time, Muslim Indians differentiated themselves by defending the secular nature of the Indian state and heralding the values of tolerance propelled by the Indian Constitution. The Indian American lobby in Washington does not endorse the Hindu-Muslim cleavage and should therefore be devoid of this religious dimension. Most groups do not indeed demonize Indian Muslims as it would fragilize their ambitions to speak for the entire community and choose instead to target Pakistan in particular or Islamism at large. The religious polarity in the wider community and the presence of a Hindu nationalist government in India (from 1998 to 2004) during the formative years of this lobby contributed to its anti-Muslim undercurrents. A third element reinforced this tendency: the Indo-Jewish alliance in the United States and the presence of long-distant nationalists in the two communities.

\section{Islamophobia and transnational mobilization}

12 As Western host-countries realized that an ever increasing number of foreign refugees or migrants come to their shores, ethnicity gradually became a fundamental factor in 
differentiating between migrant communities and allocating national resources, through positive discrimination for example. Nathan Glazer and Daniel Patrick Moynihan had already noted it in 1975. Critics and protectionists still currently fear that these migrants bring with them the ethnic strife that often rendered life in their home country difficult. This fear is supported by evidence of communal conflict imported from the homeland (Sheffer 2003: 201). To some extent, the India-Pakistan hostility and the Hindu-Muslim cleavages among South Asian Americans illustrate this. It stems from the nature of migration and from long-distance nationalism fostered by the experience of uprooting.

\section{Long-distance nationalism}

13 Many theorists of nationalism have observed the 'internationalization of nationalism' to borrow A. D. Smith's description (Smith 1999: 98). Ernest Gellner for instance devoted a chapter of his book Nations and Nationalism to 'the nationalism of diaspora', which he identifies as 'the third variant of nationalism' concerning a minority group, whether ethnic or not, in a host country (Gellner 1989). But Benedict Anderson's definition of long-distance nationalism really constitutes a landmark in theoretical thinking. He uses this concept as a counter-argument to the idea that the rise of transnational groups had made nationalism obsolete (Anderson 1992: 4). On the contrary, he argues that this peculiar kind of nationalism breeds upon migration, mass communication and ethnicity:

The vast migrations produced over the past 150 years by the market, as well as war and political oppression, have profoundly disrupted a once seemingly 'natural' coincidence of national sentiment with lifelong residence in fatherland or motherland. In this process 'ethnicities' have been engendered which follow nationalisms in complex and often explosive ways (...). It may well be that we are faced here with a new type of nationalist: the 'long-distance nationalist' one might perhaps call him. For while mechanically a citizen of the state in which he comfortably lives, but to which he may feel little attachment, he finds it tempting to play identity politics by participating (via propaganda, money, weapons, any way but voting) in the conflicts of his imagined Heimat-now only fax-time away. But these citizenshipless participation is inevitably non-responsible-our hero will not have to answer for, or pay the price of, the long-distance politics he undertakes. He is also easy prey for shrewd political manipulators in his Heimat (Anderson 1992: 10, emphasis added)

14 In the last twenty years, South Asian communities in diaspora have been particularly prone to long-distance nationalism and one can easily recall the Sikh diaspora's support to the Khalistani project and the Tamil diaspora's support to the LTTE rebellion. In a way, the Ghadar Party partook of the same logic. Several factors contribute to the assumption that the first generation of Indian Americans, who became involved in politics in the 1980s and 1990s, do so as long-distance nationalists and tenets of foreign hindutva, either because of the psychological trauma caused by migration or by the necessity to define themselves in migration by opposition with an essentialized Other. Ashis Nandy favours the first explanation and links long-distance nationalism amonsgt NRIs and PIOs to the insecuriy resulting from uprootedness, cultural alienation and a minority position. Endorsing the cause of India and identifying with Hindu nationalism for instance and its demonization of Islam could then be interpreted as 'a symbolic redress of cultural defeat' (Nandy 2000: 127-50, 164-170) and 'compensatory gratification' (Rajagopal 2001: 47). Most specialists of diasporas or of Indian Americans in particular, like Walker Conner, Paramatama Saran, Philip J. Leonhard-Spark and Monisha Das Gupta, follow this 
psychological explanation and emphasize the migrant's emotional need for a national sentiment (Conner 1986: 16, Saran \& Eames 1980: 170, Das Gupta 1997).

However, post-1965 Indian migrants to the U.S. have now secured a comfortable position in the American middle to upper class and are widely acknowledged as a successful and hardworking group. Many of them have sought to assimilate in the American mainstream and have acquired U.S citizenship. Their defiance towards Islam and their leaning towards the Sangh Parivar and its overseas network cannot therefore be attributed solely to an emotional instability. According to Frederic Barth's interactionist theory of 'ethnicity boundaries', developed in Ethnic Groups and Boundaries: the Social Organization of Cultural Difference, an ethnic group is not primarily defined by its primordial characteristics but by what differentiates it from other groups. Differences with other social groups matter more than similarities among the members of an ethnicity and the identification of an Other serves as an identity marker (Barth 1969). Hindutva, with its distancing of the Muslim community as foreign invaders, provided a potent ideology for Indian Americans in search of a separate identity since the late 1970s. Indeed, they lobbied for the creation of a separate entry in the Census and were listed as 'Asian Indians' for the first time in 1980, before being officially labeled 'Indian Americans' in the 1990s (Sabbagh 2003). Moreover the constitution of the Indian American lobbies coincided with the rise of hindutva in India. The frequent visits of Indian dignitaries in the U.S. and the rapid rise of the instrumentalization of the Internet towards this end, with the creation of websites like www.hinduunity.org, a pro-hindutva and Muslim-bashing umbrella site based in Queens and Long Island, further fuelled 'Yankee hindutva'.

The scandal about the funds of the India Development and Relief Fund (IDRF) in September 2003 brought to light the Sangh Parivar's international networks and the participation of the Indian diaspora, and mostly of Indian Americans, in the Hindu nationalist project. Indeed, a report showed with ample evidence that the IDRF, a taxexempt charity based in Maryland, had channelled money to projects headed by the RSS or its subsidiaries in India. ${ }^{15}$ While many donors, whether individuals or corporate had unwittingly participated in this extremist project, the IDRF scandal however revealed the extent of pro-hindutva sympathies among Indian Americans. After all, the Vishwa Hindu Parishad (Hindu World Council, the religious branch of the Sangh Parivar) had opened its branch in the U.S. in as early as 1970, while the IDRF had been created in 1989 two years before the Overseas Friends of the Bharatiya Janata Party (OBJP). In the 1990s, Sangh subsidiaries flourished on American university campuses and numerous websites based in America broadcasted the hindutva ideology. Of course, the younger generation of $A B C D$ (American-Born Confused Desis) has been particularly targeted by nationalist student organizations who adopted a very didactic approach with summer camps and Hindi classes for beginners, while 'many of the uncles and aunties belong or have sympathies for the OBJP' as remarked the President of IALI, who wished to differentiate himself from long-distance nationalism. Anyhow, the fact that the Legislative Assistants of Congressman Joseph Crowley and Congressman Joe Wilson (the two co-chairs of the India Caucus) never mention and never work with Indian Muslims, while they maintain frequent contacts with the Indian American lobbies, further hints at the penetration of a largely Hindu-bias in the Indian American political representation. However, the fear of the Muslim projected as the irredeemable Other could not have crept into the rhetoric of leading Indian American lobbyists had it not been supported by the American system, 
which increasingly considers ethno-religious affiliations as potent modes of political representations.

\section{From Kashmir to Palestine: the Indo-Jewish nexus}

17 It was only natural for the Indian American lobby to look at the Jewish lobby for guidance as a model of political action. Indian Americans wished to emulate the strength of the American Jewish lobby and Kumar P. Barve, the first Indian American holding office since Dalip Singh Saund's election to the Congress 1956, sums this interest up by stating that 'Indian Americans see the American Jewish community as a yardstick against which to compare themselves. It's seen as a gold standard in terms of political activism. ${ }^{16}$ However, in spite of the Jewish lobby's position as the most prominent ethnic lobby in the U.S., this rapprochement is a recent phenomenon very much linked to long-distance nationalism in the two communities and to the rise of hindutva in India.

The Sangh Parivar itself encouraged such an alliance and hoped it would become an antiMuslim front. According to Vijay Prashad, a leftist academic settled in the U.S., the IndoJewish friendship in America is very much linked to the rise of right-wing nationalists, personified by Sharon and Advani, in Israel and in India. He attributes it to the 'Global Right' and to 'the entente between India and Israel, between Hindutva and Sharonism in the shadow of US imperialism' (Prashad 2003: 4-5, 7). Of course, K.B. Hedgewar, the founding father of the RSS, and Veer Savarkar, the author of the 1923 pamphlet Hindutva. Who is a Hindu?, professed their admiration for Nazism and Fascism and wished to import the idea of a Final Solution to the Muslim Indian community. However, the Sangh Parivar soon distanced itself with this embarrassing position and sought on the contrary to embrace the Jewish community, seen as a model of financial strength and nationbuilding. The New Jew, a strong and young man, fighting for an independent nation surrounded by hostile Muslim countries was an attractive image for the Sangh, an organization aspiring at the moral, physical and religious rejuvenation of a Hindu India. Besides, the Palestinian-Israeli conflict and Palestinian terrorism provided a tempting parallel for the Hindu-Muslim communal tension and Kashmiri militancy in the eyes of Sangh activists. Many BJP and Bajrang Dal leaders have thus spoken highly of Jews and Israel. The Indo-Israel friendship was subsequently supported by the BJP government. This new friendship was of course encouraged by the Indian government seeking to ally itself with Israel, for strategic and military purposes. An influential Jewish American defense lobbyist and the director of the Jewish Institute for National Security Affairs (JINSA) works frequently with the Indian American community and was one of the first professional lobbyist to be interested in India. He recalls his first visit there in 1997 and says that 'General J. F. R Jacob [an Indian Jewish general famous for his victory over Pakistani forces in the 1971 war and for having been the BJP's security adviser] hosted a party at his house, where we met BJP officials including Jaswant Singh [Minister of External Affairs and then of Finance during the second term of the BJP]. Here the State Department only said 'Congress' and the Congress said that the BJP were extremists. But Jacob said they were important and had a chance in the elections. They actually helped increase the relationship with Israel (...) Also, Madhav (Monu) Nalapat [an academic who has been directly involved in the India-China and the India-Us-Israel talks] helped. He is Muslim but he is also a friend of Murli Manohar Joshi [a prominent BJP and RSS leader]. ${ }^{{ }^{17}}$ The involvement of the BJP in India and of the Sangh Parivar abroad in the Indo-Jewish 
diasporic friendship led to the creation of what was perceived as an anti-Muslim front in the U.S.

The Internet proved to be a potent instrument of long-distance nationalism, which, as Benedict Anderson pointed out, feeds upon mass communications. In June 2001, the New York Times journalist Dean E. Murphy could therefore write that 'Two Unlikely Allies Come Together in Fight Against Muslims'. Indeed, the site www.hinduunity.org was supported by the extremist U.S. followers of the late Rabbi David Kahane, who wanted to throw the Arabs out of Israel (Prashad 2003: 73). ${ }^{18}$ When the website of the Bajrang Dal featuring a hitlist was closed down by the American authorities, the Hatvika Jewish Identity Center came to its rescue and put it back on the Internet. Now that it is back online, the pro-hindutva website has posted links to several extremist Jewish organizations under the subtitle 'Israel Forever'. Recently another Hindu nationalist site posted by an Indian resident and entitled Israel Storm (this site no longer exists) exposed Muslim atrocities in Israel and Kashmir and extolled Indian citizens to elect anti-Muslim leaders. ${ }^{19}$ Indeed, this alliance thrives on Islamophobia as a linking factor between the two communities and the hindtuva sites often compare Kashmir to Palestine. For instance, Rohit Vyasmaan, an activist involved in maintaining the Hindu Unity website, was quoted in the New York Times saying 'We are fighting the same war (...) Whether you call them Palestinians, Afghans or Pakistanis, the root of the problem for Hindus and Jews is Islam'. ${ }^{20}$ Moreover, the hindutva ideology rose in India at the time when the Indian American lobbies were getting organized and certainly permeated its way through its opinion about Islam. All the more so that the BJP government encouraged the Indo-Jewish official and diasporic entente.

The 9/11 attacks provided another pretext for the reactivation of long-distance nationalism in Indian American lobbies and for anti-Muslim ravings. Not surprisingly, the Kashmir-Palestinian parallel is being invoked again, in a way reminiscent of the hindutva websites, while the Internet is acknowledged as a political media. The following conversation among USINPAC members exemplifies this anti-Muslim hindutva penchant:

Senor Legislative Counsel (SLC): 'I joined USINPAC because I was blown away by 9/11. I could have been there. After that, I saw the US-India relationship from the point of view of strategic affairs and defence issue. But I have no personal gains in this. A unique perspective and voice that has to be brought to bear. My father worked at 33, Liberty Plaza and I had so many meetings at the World Trade Center. It changed everything for me. I knew people in the Pentagon who could have died.' Director Media and Communications (DMC): 'I know five people who had really close calls. And one of my close friends suffered severe burns.'

SLC: 'The World Trade Center is where we used to hang out, there was a Barnes \& Nobles and we spent a lot of time there. There are many people like that at USINPAC. For this reason, terrorism is one of our highest issues, even for the second generation.'

DMC: 'I am a Gujarati from Bombay and I came to the US nine years ago. Because of all this, NRIs, Indians and PIOs are scared to travel. There are jihadi websites that target us. It's impossible to go anywhere!'

SLC: 'At the same time, India-Israel ties made sense after 9/11. After that, we see the connections. They (the terrorists) got to work together!'

DMC: 'I have a friend who did a PhD in Israel, at the Wiseman Institute. There are actually many Indians in Israel.'

SLC: 'Sanjay's [Sanjay Puri, the director and founder of USINPAC] family came from Lahore originally but they were thrown out during Partition. Half of his family died. It was a bloodbath. They finally settled in Ahmedabad. With 9/11, the same thing happened here. His personal bond with the AJC [American Jewish Committee] and 
AIPAC [American Israel Public Affairs Committee] is because of that. He really reached out to create a coalition for that one issue - terrorism. Hence the importance of educating people of this issue. One of the reasons USINPAC came together is because of $9 / 11$ not because it is an instrument for their members' ego or agenda. They joined out of fear and helplessness.'

Intern: 'For the second generation, that (...) 9/11 (...) created a link between the World Trade Center and Kashmir. It's the same kind of people who did it, the same kind of ideology.'

These three interviewees belong to different generations of Indian Americans and have a very different degree of familiarity with the lobbying game. The Senior Legislative Counsel of USINPAC is a middle-aged professional lobbyist, while the Director of Media and Communications is a younger civil servant with less experience and the intern a twenty-something graduate belonging to the second generation of Indian Americans. None of them have been directly exposed to Islamic terrorism and yet they link Partition, friendship with the Jewish lobby, the 9/11 attacks and the Kashmiri insurgency to Islamic terrorism, which henceforth becomes the absolute evil against which different communities have to unite. President Bush's idea of an 'axis of evil' once again gave some legitimacy to this analogical thinking three years after the $9 / 11$ attacks. Thus fighting terrorism, more than working for development, has become the core issue for the vast majority of Indian American lobbies. Even AAPI has turned to terrorism as one of its main concerns and addressed it along with healthcare issues, philanthropy and the India-U.S. relationship at its $20^{\text {th }}$ annual convention held in Chicago in June 2002. A report prepared by AAPI in March 2002 and entitled India-U.S. Relations in the Aftermath of September 11, 2001, also put Kashmir and Palestine at the same level as instances of communal conflict with remarks such as 'the thinking goes that if U.S. can bomb Afghanistan, Israel can bomb Palestinian hideouts, why can't India bomb the terrorist camps in Pakistan occupied Kashmir or in Pakistan!'. ${ }^{21}$ The Kashmir-Palestinian equivalence is certainly not derived from an official Indian position. On the contrary, the similarity between the two regions is being used by the Muslim Hurriyat Conference to pressurize the Indian government to evacuate Kashmir in the way Israel evacuated Gaza. ${ }^{22}$ The parallel between Palestine and Kashmir is therefore not essentially anti-Muslim and can on the contrary be instrumentalized to further the Muslim Kashmiri cause. The Islamophobia among Indian Americans, their focus on terrorism and their conflation of Palestine and Kashmir has to be understood as a by-product of the American dominant political rhetoric and of Jewish and Hindu long-distance nationalisms.

\section{Conclusion}

Several questions arise from the observation that the Indian American lobbies have a tendency to identify Islam as the irredeemable Other. To begin with, what is the influence of this hostility on inter-communal relations in the U.S.? Moreover, do the Indian American lobbies really influence the American foreign policy towards Muslim countries and Pakistan in particular? The answers to both interrogations go beyond the scope of this article. However, the Indo-Jewish nexus in Washington, the Congressional Caucus on India and the Indian Americans do target Pakistan as a primary concern of U.S. foreign policy. This anti-Muslim streak has also permeated the political position of many Congressmen, who tend to lump together Israel and India's concerns. The space devoted to the Indian American lobby in the press tends to give it undue importance in the 
process of political decision-making. Of course, the actual power of this lobby needs to be carefully accessed but measuring influence is an elusive task. Islamophobia amongst Indian American lobbyists indicates that they try to gain influence by aligning themselves with what they perceive as the mainstream American discourse. On the other hand, one can wonder if this strategy will prove fruitful in a country that is increasingly critical of overly sectarian positions. Indeed, the recent sales of F-16 planes to Pakistan and the Pakistan-U.S. friendship since 2001 clearly indicate the limited influence of the Indian American Islamophobia and the Indian American lobbies. Eventually, the Indian American lobbies in Washington and the pro-hindutva expatriates tell only one side of the Indian diaspora story in the U.S. There are many groups and publications, like Promise of India or Samar, which are fighting communalism. The recent scandal about the controversial Indian Chief Minister Narendra Modi reveals the oppositions and the diversity of the Indian American community. Narendra Modi, often exposed as the instigator of the 2002 anti-Muslim pogroms in Gujarat, had been denied his visa to the U.S. where he had been invited by the AAHOA-New York. The American authorities had refused the India official the right to set foot on its territory thanks to the action taken by several groups, including Indian Americans fighting for secularism. A three-fold conclusion can be drawn from this episode: firstly, Islamophobia is far from being a consensual view among Indian Americans, secondly academically-oriented secular activists both on the West and on the East coast can sometimes counter the work of New York or Washington-based ethnic lobbies, and finally the idea of India is still fiercely debated among the diaspora.

\section{BIBLIOGRAPHY}

Abélès, Marc (2002) Les nouveaux riches: un ethnologue dans la Silicon Valley, Paris: Editions Odile Jacob.

Ambrosio, Thomas (2002) 'Ethnic Identity Groups and U.S. Foreign Policy', in Thomas Ambrosio (ed.), Ethnic Identity Groups and U.S. Foreign Policy, Westport (Connecticut): Praeger.

Anderson, Benedict (1992) ‘The New World Disorder', New Left Review, 193, pp. 4-11.

Babu, Ramesh (1989) 'The Indian Americans: A Minority in Making’, in Ramesh Babu (ed.), Minorities and the American Political System, New Delhi: South Asian Publishers.

Barth, Fredrik (1969) Ethnic Groups and Boundaries: The Social Organization of Cultural Difference, London: Allen \& Unwin.

Conner, Walker (1986) 'The Impact of Homelands upon Diasporas', in Gabriel Sheffer (ed.), Modern Diasporas in International Politics, London: Croom Helm, pp. 16-45.

Das Gupta, Monisha (1997) “What is Indian about You?': A Gendered, Transnational Approach to Ethnicity', Gender and Society, 11(5), pp. 572-96.

Dumm, Christopher; Jain, Nisha (2004) A Portrait of the Indian American Community: An In-Depth Report based on the U.S. Census, New York: The Indian American Center for Political Awareness. 
Gellner, Ernest (1989) 'Le nationalisme de diaspora', Nations et nationalisme (1983), [trad. Bénédicte Pineau], Paris: Payot, pp. 146-56.

Glazer, Nathan; Moynihan, Daniel Patrick (eds.) (1975) Ethnicity: Theory and Experience, Cambridge (Massachusetts): Harvard University Press.

Glick Schiller, Nina (1999) 'Transmigrants and Nation-States: Something Old and Something New in the U.S. Immigrant Experience' in Charles Hirschman, Philip Kasinitz \& Josh Dewind (eds.), The Handbook of International Migration: The American Experience, New York: Russell Sage Foundation, pp. 94-119.

Gosine, Mahine (1990) Dot-Headed Americans: The Silent Minority in the United States, New York: Windsor Press.

Guthikonda, Ravindranath (ed) (1979) Indian Community Reference Guide and Directory of Indian Associations in North America, New York: Federation of Indian Associations.

Khagram, Sanjeev; Desai, Manish; Varughese, Jason (2001) 'Seen, Rich, but Unheard? The Politics of Asian Indians in the United States', in Gordon H. Chang (ed.), Asian Americans and Politics: Perspectives, Experiences, Prospects, Washington: Woodrow Wilson Center Press/Stanford University Press.

Kurien, Prema (1997) 'Constructing 'Indianness' in the United States and India: the Role of Hindu and Muslim Indians Immigrants', www.usc.edu/dept/geography/sc2/sc2/pdf/kurien.pdf

Mathew, Biju; Prashad, Vijay (2000) 'The Protean Form of Yankee Hindutva', Ethnic and Racial Studies, 3(3), pp. 516-34.

Mohammad-Arif, Aminah (2000) 'The Lobbying Game of the Indian and Pakistani Diasporas in the U.S.', http://www.ceri-sciences-po.org

Nandy, Ashis (2000) 'Themes of State, History, and Exile in South Asian Politics: Modernity and the Landscape of Clandestine and Incommunicable Selves', in Vinay Lal (ed.), Dissenting Knowledge, Open Futures: The Multiple Selves and Strange Destinations of Ashis Nandy, New Delhi: Oxford University Press.

Prashad, Vijay (2003) Namaste Sharon: Hindutva and Sharonism under U.S. Hegemony, New Delhi: LeftWord Books.

Rajagopal, Arvind (2001) Politics after Television: Hindu Nationalism and the Reshaping of the Public in India, Cambridge: Cambridge University Press.

Reeves, Terrance J; Bennett, Claudette E. (2004) 'We the People: Asians in the United States', Census 2000 Special Reports, 17, http://www.census.gov.

Robertson, Roland (1992) Globalization. Social Theory and Global Culture, London: Sage.

Sabbagh, Daniel (2003) 'Le statut des ‘Asiatiques’ aux Etats-Unis: L’identité américaine dans un miroir’, Critique internationale, 20, pp. 69-92.

Saran, Parmatma; Eames, Edwin (eds.) (1980) The New Ethnics: Asian Indians in the United States, Westport (Connecticut): Praeger.

Segal, Uma A. (1999) 'A Silent Asian Minority: the Asian Indian', Current Politics and Economics of Asia, 6(4), pp. 231-53.

Shain, Yossi (1999) Marketing the American Creed Abroad: Diasporas in the U.S. and Their Homelands, Cambridge: Cambridge University Press.

Sheffer, Gabriel (2003) Diaspora Politics: At Home Abroad, Cambridge: Cambridge University Press. 
Smith, Anthony David (2001) Nationalism: Theory, Ideology, History, Cambridge: Polity Press.

Smith, Tony (2000) Foreign Attachments: The Power of Ethnic Groups in the Making of American Foreign Policy, Cambridge (Massachusetts): Harvard University Press.

USINPAC: http://www.usinpac.com

\section{PRIMARY SOURCES}

\section{Reports}

Embassy of the United States of America (2004) 'People, Progress, Partnership: the Transformation of US-India Relations', in People, Progress, Partnership: the Transformation of USIndia Relations, New Delhi.

Federal Election Commission, 'Individuals Who Gave to this Committee', http:// query.nictusa.com/cgi-bin/com_ind/C00381699

Bothra, Raj (ed.) (2002) 'India-U.S. Relations in the Aftermath of September 11, 2001', American Associations of Physicians from India, www.ccsindia.org/indous.pdf

National Foreign Intelligence Board (National Intelligence Council/ Central Intelligence Agency) (2000) Global Trends 2015: A Dialogue About the Future With Nongovernment Experts, http:// www.cia.gov/cia/reports/globaltrends2015.

Sabrang Communications Private Limited (Mumbai) and The South Asia Citizens Web (France) (2002), The Foreign Exchange of Hate: IDRF and the American Founding of Hindutva, www.stopfundinghate.com

\section{Newspaper articles}

‘Geelani Compares Kashmir with Palestine Dispute', The Kashmir Times, 20 August 2005, http:// www.kashmirtimes.com/

Cooperman, Alan 'India, Israel Interests Team Up', The Washington Post, 19 July 2003, http:// www.washingtonpost.com/ac2/wp-dyn/A13526-2003Jul18?language=printer.

Murphy, Dean E., 'Unlikely Allies Come Together in Fight Against Muslims', New York Times, 2 June 2001, p. 1.

\section{Interviews}

President of South Asians for Kerry (SAKI) (2004). Interview by author, 3 August, New York. Senior Fellow-International Affairs \& Indian-Jewish American Relations (2004). Interview by author, 6 August, Washington.

Director of the Jewish Institute for National Security Affairs (JINSA) (2004). Interview by author, 6 August, Washington.

Executive Director of the Indian American Center for Political Awareness (IACPA) (2004). Interview by author, 9 August, Washington.

Legislative affairs counsel of USINPAC (2004). Interview by author, 10 August, Washington. 


\section{NOTES}

1. I wish to adopt Thomas Ambrosio's definition of ethnic lobbies as political organizations established along cultural, ethnic, religious, or racial lines that seek to directly and indirectly influence U.S. foreign policy in support of their homeland and/or ethnic kin abroad.

2. $63,25 \%$ of Indian Americans are 35 year old or under, while only 51,12\% of the total U.S. population is under $35.83,37 \%$ of Indian Americans hold a university degree, compared to only $33,24 \%$ of the total population. $97,70 \%$ of Indian Americans live in urban areas, whereas it is only the case for $79 \%$ of Americans. Besides the median income among Indian American families is more than $20000 \$$ higher than the median income in non-Hispanic White families.

3. http://www.garamchai.com/desiassc.htm and http://www.garamchai.com/ indassc.htm\#Arkansas. The total number of association is however supposedly much higher and this listing only mentions associations using the electronic media.

4. According to a directory published in 1979, there were 200 Indian American associations in the country.

5. From the home page of USINPAC: http://www.usinpac.com.

6. Senior Fellow - International Affairs \& Indian-Jewish American Relations, interview with the author, 6 August 2004, Washington.

7. Legislative affairs counsel of USINPAC, interview with the author, 10 August 2004, Washington.

8. Executive Director of the Indian American Center for Political Awareness (IACPA), interview with the author, 9 August 2004, Washington.

9. President of South Asians for Kerry (SAKI), interview with the author, 3 August 2004, New York.

10. 'Individuals Who Gave to this Committee', Federal Election Commission, http:// query.nictusa.com/cgi-bin/com_ind/C00381699

11. National Foreign Intelligence Board (National Intelligence Council/ Central Intelligence Agency), Global Trends 2015: A Dialogue About the Future With Nongovernment Experts, December 2000, pp. 1-85, 11, 18, http://www.cia.gov/cia/reports/globaltrends2015. Besides, the importance of the Indian American community in particular is highlighted in: Embassy of the United States of America People, Progress, Partnership: the Transformation of US-India Relations, New Delhi, India, 2004, $127 \mathrm{p}$.

12. 'The genealogy of ethnic involvement in U.S. foreign policy should be traced back to the first time this British orientation resulting from the glorification of the Anglo-Saxon race was confronted and challenged.'

13. Thomas Ambrosio uses the term 'intermestic'.

14. 'Religion in this country comes to sustain immigrant ethnicity'.

15. Sabrang Communications Private Limited (Mumbai) and The South Asia Citizens Web (France), The Foreign Exchange of Hate: IDRF and the American Founding of Hindutva, 20 November 2002, 87p., www.stopfundinghate.com

16. Alan Cooperman, 'India, Israel Interests Team Up', The Washington Post, 19 July 2003, http:// www.washingtonpost.com/ac2/wp-dyn/A13526-2003Jul18?language=printer. Interestingly, the integral text of this article features on the website of the Hindu Vivek Kendra, a Sangh Parivar outlet: http://www.hvk.org

17. Director of the Jewish Institute for National Security Affairs (JINSA), interview with the author, 6 August 2004, Washington.

18. Dean E. Murphy, 'Two Unlikely Allies Come Together in Fight Against Muslims', New York Times, 2 June 2001, p. 1. 
19. In a private electronic correspondence, the webmaster, who remained anonymous, wrote that 'This site was inspired by the www.masada2000.org website. Yes, truth hurts but that's the way it is. I have never met a Jew in all my life sitting in India. But I am hugely interested in their culture and customs. Would love to go to the holy city of Jerusalem, the capital of Israel sometime' [sic]. Anonymous, hello. [electronic message], to: Ingrid Therwath, 14 August 2004 [personal message].

20. Dean E. Murphy, op. cit.

21. Raj Bothra (ed.), India-U.S. Relations in the Aftermath of September 11, 2001, American Associations of Physicians from India, 22 March 2002. Available on www.ccsindia.org/indous.pd 22. 'Geelani Compares Kashmir with Palestine Dispute', The Kashmir Times, 20 August 2005, http://www.kashmirtimes.com/

\section{ABSTRACTS}

In the past few years, the Indian American community has gained an unprecedented visibility in the international arena. It is indeed often projected as a model community and now constitutes growing and influential ethnic lobbies in Washington. But, in the face of its sheer division, Islamophobia did provide a unifying force sometimes bigger than the interest of Indian Americans or of their country of origin. Other factors can also be summoned. Among them, a leniency of many post-1965 migrants towards Hindu nationalist ideology and the wish to align with Jewish pressure groups in the context of the war against terrorism and to further the IndiaIsrael-US strategic partnership play a major role in explaining Islamophobic overtones in the Indian American lobbies. 